\title{
The Many Faces of Internet Marketing
}

\author{
Aleksandar Grubor \\ University of Novi Sad, Faculty of Economics in Subotica, Serbia \\ Olja Milovanov \\ University of Novi Sad, Faculty of Economics in Subotica, Serbia
}

\section{Abstract}

In the last decade marketing discipline has been revolutionized. Internet marketing in now considered to be one of the fastest growing branches of marketing theory and practice, which has emerged as a direct response to fast-growing and changing market landscape. The power of the web has transformed both consumer behaviour and lifestyle and traditional marketing strategy path towards completely new patterns that has become an imperative in modern business surroundings. Thus, the intention of this paper is to examine all faces of Internet-based marketing and to highlight all challenges and opportunities that should be addressed today, and in the near future, in the context of Internet as a centre of business operations. Relying on the results of research and analysis in the given field, it is clear that internet improvements are going to create even more dynamic and challenging environment in just next few years, and that embracing digital marketplace rules and engaging in full range of internet marketing activities is vital for companies across all industries.

Keywords: internet marketing, digital marketing, online marketing, innovation, ICT JEL classification: M31

\section{Introduction}

Globally, the number of web sites increased from 17 million in 2000 to 1 billion in 2014 (Internet Live Stats, 2017). Worldwide business-to-consumer e-commerce sales increase by $20.1 \%$ in 2014 reaching $\$ 1.500$ trillion (eMarketer, 2014). There is an expansion of online and mobile users across the globe, especially from emerging markets, $\mathrm{m}$-commerce sales is constantly rising, shipping and payment options have been simplified and major global brands have been pushed into new international markets (eMarketer, 2014). The age of Internet and digitalization is here.

Following improvements in mobile and tablet technology, together with social media, marketing has set itself in a new, complex and challenging market environment. Internet has become the primary business playground and the most popular communication channel, and Internet marketing and e-commerce have emerged as a major preoccupations and business skills in all industrial branches. Traditional marketing methods are becoming both ineffective and expensive (Vaughan, 2013).

Thus, the intention of this paper is to examine all faces of Internet-based marketing and to highlight all challenges and opportunities that should be addressed today, and in the near future, in the context of Internet as a centre of business operations. Relying on the results of research and analysis in the given field, it is clear that internet improvements are going to create even more dynamic and challenging environment in just next few years, and that embracing digital marketplace rules 
and engaging in full range of internet marketing activities is a necessity for companies across all industries.

\section{Digital vs. Internet marketing}

Digital marketing also known as internet marketing, online marketing, web marketing or data-driven marketing, is a broad term for a group of marketing processes that exploit all available digital channels and internet tecnologies with the aim of promotion of branded products and services. Its development is a direct result of the increased electronic data, digital media usage and its impact in business sphere globally.

The development of digital marketing is primarily related with internet, which is the reason why it has so many manifestations. However, Digital marketing and Internet marketing are not the same things (Atshaya \& Rungta, 2016). Digital marketing is wider term that includes both online and offline digital technologies and multiple channels under it, while Internet marketing bases its activities only on the internet. Some of digital marketing channels are "sms marketing, digital print ads, television marketing, radio advertising, etc." (Atshaya \& Rungta, 2016, p. 29). As well, it covers web, search, social media, e-mail, digital advertising and media buying (Sweetwood, 2016).

Both are very effective in conducting, analysing and measuring total effects of marketing campaigns. In the following, the accent will be on the internet marketing.

\section{Internet marketing channels}

Although, beginnings of Internet marketing are associated with advertising boom and first versions of search engine optimisation (SEO) in 1995 (Jones, Malczyk \& Beneke, 2013), today, it is an umbrella term for "email marketing, search engine optimization, social media marketing, pay per click, display ads on websites, gaming advertising, search engine marketing, call back or hold-on mobile ring tone, etc." (Atshaya \& Rungta, 2016, p. 30). Internet marketing is a subset of Digital marketing, its main component, and it exploits dominantly internet channel for the promotion of brands (Atshaya \& Rungta, 2016). Major channels of Internet marketing are shown in the Figure 1.

Figure 1

Major channels of Internet marketing

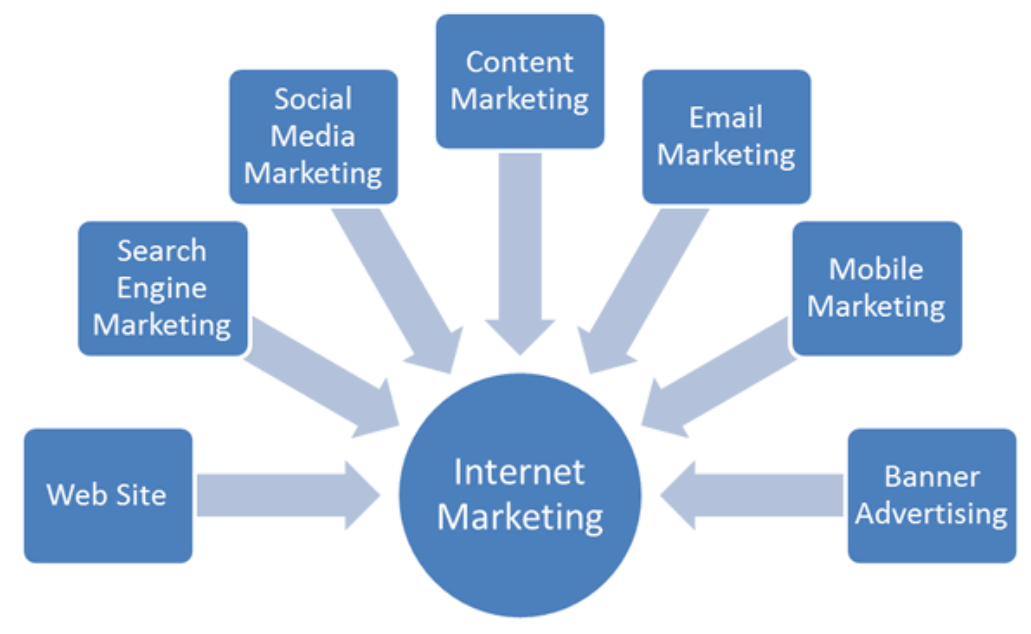

Source: Chris, 2017 
Web site is a starting point in online marketing campaign and communication with customers (Chris, 2017). It is a "place" in digital space "owned" by a company, where all information about the company and its products can be found. This is also the final destination of all banners, social media profiles, texts and similar content that exist across the Internet about the company.

Search Engine marketing (SEM) is a tool for increasing visibility of a company's website and making online promotion of a company more effective. It uses paid advertisements links (pay per click platforms - e.g. Google Adwords) and Search engine optimization (e.g. Google, Bing, Yahoo) for acceleration of website traffic specifically, the aim is to attract as many targeted users as possible and to increase visits to a website and awareness of company's brands (Chris, 2017). In this process, special attention should be put on the process of designing unique and attractive content for the targeted audience.

Social media marketing is "an innovative tool that organizations use for creating a very strong public relation with the customers on the virtual networks" (Jan \& Khan, 2014). Social media platforms (e.g. Facebook, Twitter, Instagram, Linkedln etc.) consist of large and various communities of customers that are not that easily available and visible in traditional channels. They help in enhancing the communication with all users, but each social media site demands different approaches, techniques and strategies of marketing.

Content marketing is "a strategic marketing approach focused on creating and distributing valuable, relevant, and consistent content to attract and retain a clearly defined audience-and, ultimately, to drive profitable customer action" (Content Marketing Institute, MarketingProfs \& Brightcove, 2015, p. 8). It is a "good story about the company that is described in hundred words, without mentioning company's references, brands and all other superlatives, and that, even without these components, carry attributes authentic, focused, and relevant" (Postma, 2014). The aim is driving and retaining customer action and interaction with company and its brands with authentic, original and inspiring content.

Email Marketing is the direct way for personal and customized communication with customers. It helps in reaching more customers and conveying a wide variety of messages in creative forms with the possibility of getting direct feedback from customers' and measuring its effectiveness easily (Atshaya \& Rungta, 2016).

Mobile marketing is about creating content or ads that is viewable and suitable for a mobile device (Chris, 2017). It implies "any marketing activity conducted through a ubiquitous network to which consumers are constantly connected using a personal mobile device" (Kaplan, 2012, p. 132). Given that smart phones are devices that are always "in the pocket" of its users, with constant connection to the Internet, the opportunity mobile marketing provides is creating fully customised information to customers, depending of their location, time, activities and other data about the person that could be tracked through mobile device and application installed on it. Display Advertising is focused on the usage of visual elements like images, videos, animations, rather than test, in creating brand awareness and image, and finally sales (Atshaya \& Rungta, 2016).

\section{Internet marketing strategy}

The creation of new positions like Chief Digital Officer (CDO), Chief Information Officer (ClO), Chief Technology Officer (CTO) and various others testify how important is for a company to keep up with trends in digital age, especially in terms of transformation of traditional organizational systems and cultures. Consulting firm Russell Reynolds Associates describes the CDO as "an individual who helps a 
company drive growth by converting traditional "analogue" businesses to digital ones, and by overseeing operations in the rapidly-changing digital sectors like mobile applications, social media and related applications, virtual goods, as well as "wild" web-based information management and marketing" (Conneally, 2012). Accordingly, in the years ahead, whole marketing discipline must be adapted to the new business climate. Understanding Internet marketing postulates and all the possibilities of its channels is the essence of new age marketing strategy.

Successful Internet marketing strategy requires integrated campaign, collaboration and coordination of all actions and actors, in order to avoid generating duplicate or unadjusted content that is not aligned with the general marketing aim. Sweetwood (2016) explained that the basic marketing specialist's skills today are associated with data management, analytics, data governance and reporting. Besides, he highlighted the role of Inbound marketing and the art of engaging with customers in every point of decision journey, by creating a "deeper and more intelligent conversation with potential customers" (p. 5).

Guidance for effective internet marketing strategy, given by Vaughan, P. (2013), emphasizes the following important ingredients of "inbound" approach:

1. creating a keyword strategy and optimising website - in order to be easy found by customers through SEO,

2. creating blog and marketing offers - driving the right people to your business and offering a value for them,

3. promoting content through social media - using the "buzz" power of social media platforms and creating a group of advocates that will engage in sharing of the company's content viral,

4. converting web site traffic into leads - transforming visitors of a web site into potential consumers

5. nurturing leads with targeted messages - staying at the top-of-the-mind of potential customers and creating a desire for purchase,

6. optimizing marketing for mobile viewing - making all content and offerings optimized for mobile devices,

7. analyzing and refining business and marketing strategies - conducting examination of marketing strategy from the beginning to the end and improving it in all points.

This guidance testifies that Internet marketing demands a holistic strategy and engagement of all the channels that are available in online space, with constant evaluation and improvement of Internet marketing manager skills and expertize. Finally, according to Jones et al., (2013) there are three general cornerstone principles of Internet marketing that are crucial for success in virtual market:

- immediacy with timely response to the audience,

- personalization,

- relevance of information.

On the other side, it is very important to be aware of all limitations and possible risks of conducting online marketing, like server and data limitations, reaching specific groups of consumers, making backups etc. that can harm a strategy, and that suggest that a company should always have a backup plan in case of their manifestation.

\section{Conclusion}

Connected world has brought both opportunities and challenges for marketing discipline. Keeping up with trends, innovations and new patterns of behaviour of both competitors and customers has became an important part of the process of 
creating distinctive competitive advantage and reaching targeted segments of customers in digital age. Virtual world provides a lot of room for improvements and creative strategic approaches - it is up to a company how will take advantage of it.

On the other side, online audience is "discerning, fragmented and cynical" more than ever (Yung, 2013). Modern customers are highly interested and active in interaction with the members of their online network, and very engaged in word-ofmouth communication, that resonates across the whole market. With everchanging, products, services and technology, timely response and adoption to a new market reality, with reaching the highest level of consumer satisfaction, requires much skill and effort. Acquaintance of the essence of Internet marketing methods and manifestations is vital in competitive business landscape. It means dealing with a variety of online business options as well as mastering new rules of internet marketing strategy.

\section{References}

1. Atshaya, S., Rungta, S. (2016), "Digital Marketing vs. Internet Marketing: A Detailed Study", International Journal of Novel Research in Marketing Management and Economics, Vol. 3 No. 1, pp. 29-33.

2. Chris, A. (2017), "Digital Marketing VS Internet Marketing - What is the latest trend?" available at: https://www.reliablesoft.net/digital-marketing-vs-internet-marketingwhat-is-the-latest-trend/ (30 March 2017)

3. Conneally, T. (2012), "Chief Digital Officer' is the next hot executive title, says Gartner." available at: https://betanews.com/2012/10/22/chief-digital-officer-is-the-next-hotexecutive-title-says-gartner/\#comment-689366865 (29 March 2017)

4. Content Marketing Institute, Marketing Profs, Brightcove (2015), "Benchmarks, Budgets, and Trends - North America." available at: http://contentmarketinginstitute.com/wp-content/uploads/2014/10/2015_B2B_ Research.pdf (29 February 2016)

5. eMarketer (2014), "Global B2C Ecommerce Sales to Hit \$1.5 Trillion This Year Driven by Growth in Emerging Markets", available at: https://www.emarketer.com/Article/Global-B2C-Ecommerce-Sales-Hit-15-Trillion-ThisYear-Driven-by-Growth-Emerging-Markets/1010575 (02 April 2017)

6. Internet Live Stats (2017), "Total number of websites", available at: http://www.internetlivestats.com/total-number-of-websites/ (03 April 2017)

7. Jan, A., Khan, M.F. (2014), "Social Media Is Nothing but a Public Relation Tool." The International Journal of Business \& Management, Vol. 2 No.12, pp. 272-277.

8. Jones, A.T., Malczyk, A., Beneke, J. (2013), "Internet marketing." available at: https://open.uct.ac.za/bitstream/item/3998/Internet_Marketing_textbook.pdf? sequen $\mathrm{ce}=1$ (01 April 2017)

9. Kaplan, A. (2012), "If you love something, let it go mobile: Mobile marketing and mobile social media 4x4 Found", Business Horizons, Vol. 55 No. 2, pp. 129-139.

10. Postma, C. (2014), "Why We Should Take the Brand out of Branded Content." available at: http://contentmarketinginstitute.com/2014/09/take-brand-out-brandedcontent/ (28 February 2016)

11. Sweetwood, A. K. (2016), "4 Roles Every Marketing Organization Needs Now", available at: https://hbr.org/2016/10/4-roles-every-marketing-organization-needs-now (27 March 2017)

12. Vaughan, P. (2013), "The Essential Step-by-Step Guide to Internet Marketing." available at: http://go.kbkcommunications.com/the-essential-step-by-step-guide-tointernet-marketing (04 April 2017)

13. Yung, R. (2013), A Comprehensive Step-By-Step Guide to Internet Marketing: The Building Blocks for succeeding with Marketing on the Web, BookBaby, New Jersey. 


\section{About the authors}

Aleksandar Grubor, Ph.D. is a Full Professor and a Dean at the Faculty of Economics in Subotica (University of Novi Sad, Serbia). He teaches Global marketing, Services marketing, Brand management, Marketing communications, Sales management, Principles of marketing and Marketing management. He is an author of 3 textbooks, 2 monographs, 8 scientific papers published in Prominent International Journals ranked in the Thomson Reuters JCR, and more than 60 scientific papers published in Journals of national importance. Besides, he participated in more than 40 International Scientific Conferences. In the period January - March 2004, he successfully completed the International Faculty Development Program at the Free Market Business Development Institute, School of Business Administration, Portland State University, Portland, Oregon, USA. Currently, he is a member of the Serbian Marketing Association (SEMA) and from 2010 to 2016 he was an Editor in chief of the Journal "The Annals of the Faculty of Economics in Subotica". Author can be contacted at agrubor@ef.uns.ac.rs.

Olja Milovanov, MSc. is an Assistant Lecturer at the Faculty of Economics in Subotica (University of Novi Sad, Serbia). Her field of interest is marketing. She teaches Principles of marketing, Product management and Business marketing. She is an author and co-author of several papers published in Journals of international and national importance, and she participated at several International scientific conferences. In June 2014 she was educated at the 2nd International Summer School on Logistics in Celje, Slovenia. Currently, she is also a member of the Serbian Marketing Association (SEMA) and Technical editor of the Journal "Annals of the Faculty of Economics in Subotica". Author can be contacted at olja.milovanov@ef.uns.ac.rs. 